\title{
EUPHORBIA SPELLENBERGIANA (EUPHORBIACEAE), A NEW SPECIES FROM MEXICO
}

\author{
Mark H. Mayfield ${ }^{1}$ and Victor W. Steinmann ${ }^{2}$ \\ ${ }^{1}$ Herbarium and Division of Biology, Ackert Hall, Kansas State University, \\ Manhattan, Kansas, 66506, U.S.A. ferguson.mayfield@gmail.com \\ ${ }^{2}$ Instituto de Ecología, A.C., Centro Regional del Bajío, Apdo. postal 386, \\ 61600 Pátzcuaro, Michoacán, Mexico. victor.steinmann@inecol.edu.mx
}

\begin{abstract}
Euphorbia spellenbergiana is described and illustrated as a new species. It belongs to subgenus Chamaesyce within which it is easily distinguished from similar species by its possession of undivided styles with capitate stigmas. This new species is endemic to Mexico and occurs from central western Chihuahua to northern Michoacán. Although widespread, it is highly habitat-specific and prospers only in the moist soil around ephemeral pools in pine-oak forest, grassland and pachycaulous scrub at elevations from 2100 to $2600 \mathrm{~m}$.
\end{abstract}

Key words: Euphorbia, Mexico, new species, subgenus Chamaesyce.

\section{RESUMEN}

Se describe e ilustra a Euphorbia spellenbergiana como especie nueva. Pertenece al subgénero Chamaesyce y se distingue fácilmente de las especies parecidas por tener los estilos sin dividir y estigmas capitados. Es endémica de México y se distribuye desde la parte centrooccidental de Chihuahua hasta el norte de Michoacán. Aunque ampliamente distribuida, tiene un hábitat altamente específico; prospera solamente en el suelo húmedo de charcos temporales en bosque de pino-encino, pastizal y matorral crasicaule, entre 2100 a $2600 \mathrm{~m}$.

Palabras clave: especie nueva, Euphorbia, México, subgénero Chamaesyce.

With approximately 250 species (Martínez-Gordillo et al., 2002; Steinmann, 2002), Euphorbia L. is one of the largest genera in Mexico, and the country repre- 
sents a major center of diversity for the genus. In the course of routine identifications of Euphorbia specimens from Mexico and in the preparation of the Flora del Bajío y de Regiones Adyacentes, we encountered specimens of an inconspicuous but widespread species that had been collected numerous times from Chihuahua to Michoacán. Despite the facts that the first gatherings were made over a hundred years ago by the renowned botanist Cyrus G. Pringle and that there are specimens in many major herbaria, the species has been overlooked until recently. The purpose of this paper is to describe this species and provide information we have on its distribution, habitat, and distinguishing characteristics.

Euphorbia spellenbergiana Mayfield \& V.W. Steinm., sp. nov. Type: MEXICO. Chihuahua: mpio. Ocampo, Parque Nacional "Cascada de Basaseachic," along the rd to the Divisadero overlook on the S side of the park, just below the Divisadero, at a drying temporary pond near hotel, $28^{\circ} 11^{\prime} \mathrm{N}, 108^{\circ} 12^{\prime} 30^{\prime \prime} \mathrm{W}$, ca. $2100 \mathrm{~m}$, moist pale gray igneous nearly dry mud, heavily cattle-trampled area, with Eragrostis pectinacea, Muhlenbergia vaginata, Eragrostis pringlei, Tillaea aquatica, Bulbostylis capillaris, 25 Oct 1992, Spellenberg 11675 (holotype: NMC!; isotypes: TEX (2 sheets)!, MEXU!). Fig. 1.

Annua prostrata, caulibus 3-7 cm longis, supra puberula, infra glabra, internodia $0.2-1.0 \mathrm{~cm}$ longa, teretia, stipulae $0.2-0.4 \mathrm{~mm}$ longae, ciliatae, folia opposita, petioli 0.2-0.9 mm longi, glabri, laminae oblongae, suborbiculatae vel subrhombeo-ovatae, 1.5-4.5 mm longae, 1-4 mm latae, bases rotundatae vel hemicordatae, obliquae, apices obtusi vel mucronati, margines integri; involucra campanulata vel obconica, $0.5 \mathrm{~mm}$ longa, 0.3-0.6 mm lata, glabra; glandulae 4, subcirculares, oblongae vel reniformes, ca. $0.1 \mathrm{~mm}$ longae (radialiter), 0.1-0.2 $\mathrm{mm}$ latae (tangentialiter), leviter concavae, appendices ut videtur ausentes vel rudimentariae; flores staminati 5-8, ovarium glabrum, styli 3, filiformes, ca. $0.2 \mathrm{~mm}$ longi, distincti, integri; capsula ovoidea, 0.9-1.1 mm longa, 1.1-1.2 mm lata, 3-lobata; semina ellipsoidea vel oblongo-ovoidea, quadrangulata, 0.7-0.9 $\mathrm{mm}$ longa, $0.4 \mathrm{~mm}$ lata, ut videtur laevigata.

Delicate annual herbs forming orbicular mats to $14 \mathrm{~cm}$ wide, with the herbage frequently reddened; roots slender, fibrous; stems prostrate, several radiating evenly from the base, often slightly zigzag, 3-7 cm long, puberulent on the upper surface with short, stiff, white, straight to slightly curved hairs less than $0.1 \mathrm{~mm}$ long, lower surface glabrous, internodes terete or slightly flattened above, those of the primary stems $0.2-1.0 \mathrm{~cm}$ long, $0.2-0.4 \mathrm{~mm}$ in diameter; leaves opposite, stipules similar on 


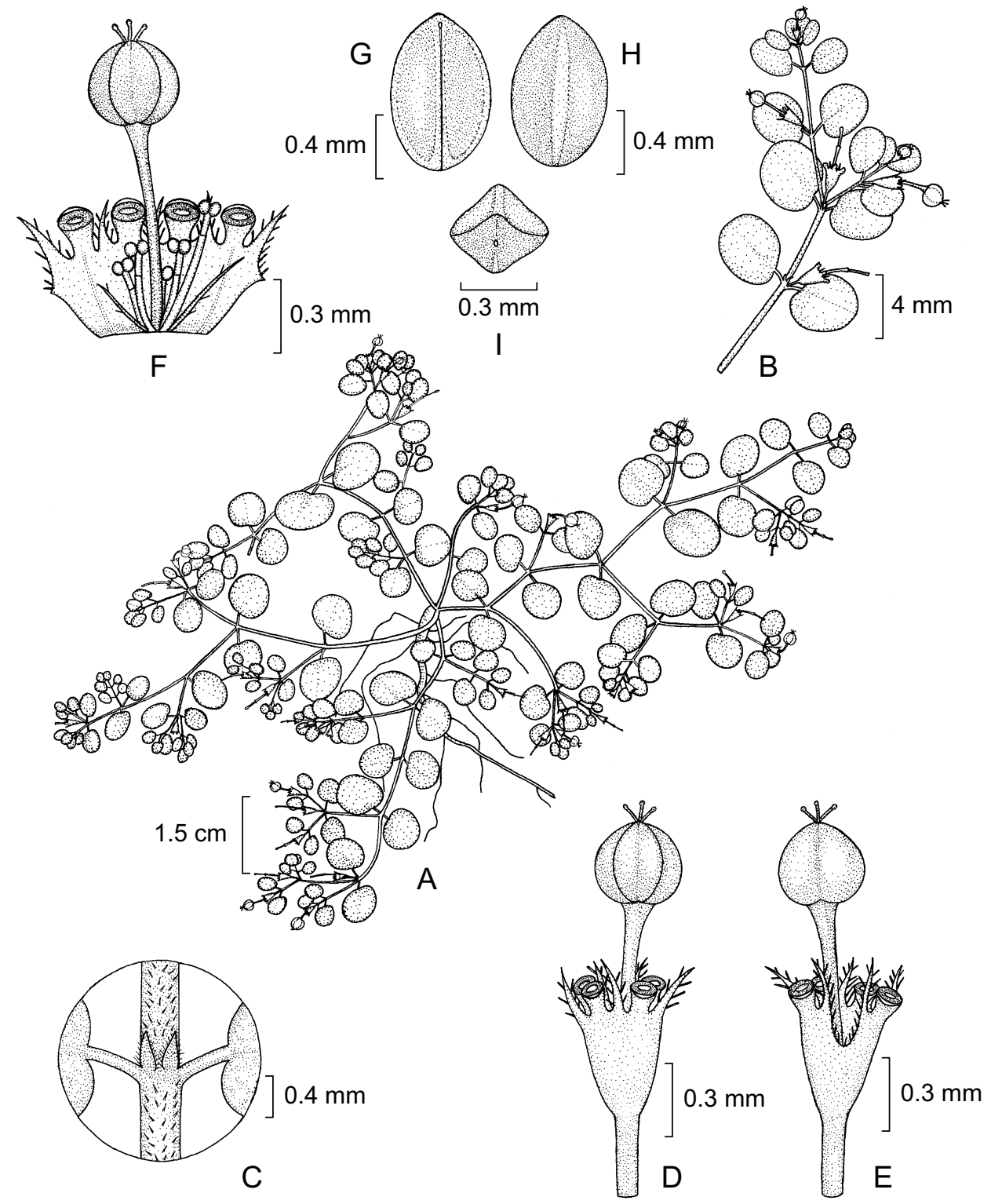

Fig. 1. Euphorbia spellenbergiana Mayfield \& V.W. Steinm. A. habit; B. flowering branch; C. stipules and leaf bases; D-F. cyathia; G. seed, ventral view; H. seed, dorsal view; I. seed, top view. All from Rzedowski 50513 (IEB). 
both sides of the stems, paired, distinct or united at the base, discontinuous between the petioles, lunate to semiorbicular or triangular, sometimes 2 to 3-lobed, 0.2-0.4 $\mathrm{mm}$ long, margins ciliate, apex acute to laciniate; petioles $0.2-0.9 \mathrm{~mm}$ long, glabrous; laminas oblong to suborbicular or subrhombic-ovate, 1.5-4.5 mm long, 1-4 $\mathrm{mm}$ wide, base strongly oblique, rounded to hemicordate, apex rounded or rarely mucronulate, margin entire; cyathia solitary or 3-7 in condensed floriferous axillary shoots in the upper 2-4 nodes, leaves of the floriferous shoots much reduced and elliptic to narrowly obovate; peduncles $0.1-0.5 \mathrm{~mm}$ long, glabrous, involucre campanulate to narrowly obconic, glabrous, ca. $0.5 \mathrm{~mm}$ long (excluding the glands and appendages), 0.3-0.6 $\mathrm{mm}$ wide; involucral lobes narrowly triangular to subulate, ca. $0.15-0.20 \mathrm{~mm}$ long, acuminate to attenuate, ciliate, protruding above the level of the glands; involucral glands 4, suborbicular, oblong or reniform, ca. $0.1 \mathrm{~mm}$ long (radially), 0.1-0.2 mm wide (tangentially), slightly concave, red, appendages absent or rudimentary and scarcely protruding from below the rim of the gland, to 0.1 $\mathrm{mm}$ long (radially) and $0.2 \mathrm{~mm}$ wide (tangentially), entire white to pink; staminate flowers 5-8; ovary glabrous, styles 3 , linear, ca. $0.2 \mathrm{~mm}$ long, distinct to the base and spreading perpendicularly, straight, undivided; stigma capitate; capsules on gynophores exserted 0.3 to $1.4 \mathrm{~mm}$, narrowly to broadly ovoid, $0.9-1.1 \mathrm{~mm}$ long, $1.1-$ $1.2 \mathrm{~mm}$ wide, 3-lobed, slightly sulcate between the carpels, columella $0.6-0.9 \mathrm{~mm}$ long; seeds elliptic to oblong-ovoid in abaxial outline, quadrangular in cross section, 0.7-0.9 mm long, $0.4 \mathrm{~mm}$ wide, bluntly pointed at the apex, rounded to truncate at the base, dorsal angle acute, subcarinate, uninterrupted, testa orangish-red to light brown, appearing smooth, but with obscure longitudinal rows of cells barely visible under 20X magnification, caruncle absent.

Taxonomic discussion. Euphorbia spellenbergiana belongs to subgenus Chamaesyce Raf., as defined by Wheeler (1941). Subgenus Chamaesyce (sensu Wheeler, 1941 ) is a widely understood concept for a monophyletic group of species that share an easily recognizable suite of morphological features (Mayfield, 1991; McVaugh, 1993). The subgenus has also been ranked as a genus (e.g., McVaugh, 1993; Mayfield, 1993; Webster, 1994) but recent phylogenetic analyses (Bruyns et al., 2006; Park and Jansen, 2007; Steinmann and Porter, 2002) demonstrate that the group is a well-supported monophyletic assemblage nested within Euphorbia (when treated as equivalent of Webster's (1994) Euphorbieae subtribe Euphorbiinae).

Euphorbia spellenbergiana is one of the most diminutive members of its genus. Despite approximately $1200 \mathrm{~km}$ separation between its most-distant populations, the plants are remarkably uniform morphologically across the geographic range. It 
resembles members of the Euphorbia polycarpa Benth. complex (as circumscribed by Wheeler, 1936) in that it is non-shrubby and possesses entire leaves. It is worth noting, however, that we suspect this assemblage of species (being defined on the basis of geography, habit and leaf morphology) almost certainly represents an unnatural, purely convenient grouping. Euphorbia spellenbergiana is at once distinguished from the members of this complex by its undivided styles with capitate stigmas (vs. bifid styles and non-capitate stigmas). Undivided styles are a very uncommon feature in Euphorbia as a whole, and in particular in species of subg. Chamaesyce. We are aware of only four other species of this taxon in northern Mexico that possess this trait: $E$. astyla Boiss., E. indivisa (Engelm.) Tidestr., E. revoluta Engelm., and E. stictospora Engelm. There is no close similarity between any of these species with undivided styles, among themselves or with E. spellenbergiana. Euphorbia spellenbergiana is a delicate completely prostrate annual, with entire, oblong to suborbicular, or ovate leaves, reduced subequal or nonexistant involucral gland appendages, smooth (nonridged) seeds, and puberulent stems. Euphorbia revoluta is an erect to ascending, glabrous species with linear leaves. Euphorbia astyla is a strongly perennial herb with a woody, thickened root and considerably larger cyathia and seeds. Euphorbia indivisa and E. stictospora are both prostrate, annual species, but they are decidedly more robust, have serrulate or serrate leaf margins, and have conspicuous pubescence on the stems, leaves, ovaries, and capsules. Euphorbia indivisa differs further in its conspicuously unequal involucral appendages and transversely sulcate seeds.

Some material of Euphorbia spellenbergiana was previously determined as either E. micromera Boiss. or E. serpens H.B.K., annual species that both possess divided styles. Besides the style difference, E. serpens is a completely glabrous plant with broad white stipules, and it roots at the nodes. The latter feature is noteworthy because specimens of E. serpens are usually extracted in small irregular pieces, owing to the adhering node roots and brittle stems. In contrast $E$. spellenbergiana specimens are without exception composed of one or more complete individual circular mats. More similar in this and other features is E. micromera; the only features that appear to unambiguously separate it from E. spellenbergiana are its divided styles and slightly longer seeds (1.1-1.3 mm vs. 0.7-0.9 mm).

Etymology. It is a pleasure to name this species after Richard Spellenberg, professor emeritus in biology at New Mexico State University. Although he was not the first person to collect this interesting plant, he was first to bring it to our attention after he encountered it more than 20 years ago in conjunction with his floristic research in the vicinity of the Cascada de Basaseachic, Chihuahua. 
Distribution and habitat. Euphorbia spellenbergiana is endemic to Mexico, ranging from central western Chihuahua south to northern Michoacán. The distance between the northernmost and southernmost populations is approximately 1200 $\mathrm{km}$. Although widespread, it is highly habitat specific and occurs only in the thin, moist soil around ephemeral pools that form during the summer monsoon season. It occurs at elevations from 2100 to $2600 \mathrm{~m}$, and the surrounding vegetation has been described as pine-oak forest, grassland and pachycaulous scrub. Although sporadic and localized, its populations are widely separated and frequently found in secondary vegetation; the majority of the collections have been made in the last twenty years. For these reasons, the species is probably not under any immediate risk of extinction.

Phenology. Flowering and fruiting overlap broadly and occur from August to November.

Additional specimens examined. MEXICO. Aguascalientes: mpio. Calvillo, $2 \mathrm{~km}$ al NW de Terrero de Refugio, 2325 m, 02 Sep 1996, de la Cerda 5830 (HUAA, IEB); mpio. San José de Gracia, cañada al SSE de km 53, carr. La Congoja - La Labor, 2600 m, 30 Oct 2001, Rosales 2145 (HUAA, IEB). Chihuahua: base of the Sierra Madre (apparently in the general vicinity of Tonachic according to Pringle's field notes published in Davis (1936)), 28 Sep 1887, Pringle 1360 (K, MEXU, MICH); mpio. Guerrero, $6.8 \mathrm{~km}$ E of Tomochic on Mexico Hwy. 16, 28 $23^{\prime} \mathrm{N}, 107^{\circ} 47^{\prime} \mathrm{W}$, ca. 2100 m, 05 Oct 1986, Spellenberg et al. 8879 (ARIZ, NMC, TEX). Durango: mpio. Durango, Parque El Tecuán, extremo NO, 03 Oct 1996, García 2486 (IEB); mpio. Durango, Parque El Tecuán, Mesa Pelona, al E de la entrada al parque, 23⒌'21" N, $105^{\circ} 01^{\prime} 33^{\prime \prime} \mathrm{W}, 2570 \mathrm{~m}, 17$ Oct 1996, González et al. 5810 (IEB); city of Durango and vicinity, Apr-Nov 1896, Palmer 819 (K, MEXU, MO). Guanajuato: mpio. Ocampo, desviación a la Estancia, 06 Oct 1992, Carranza et al. 4299 (IEB); mpio. San Diego de la Unión, alrededores de La Sauceda, km 114 carretera Querétaro - S.L.P., 11 Sep 1997, Pérez et al. 3708 (IEB). Michoacán: mpio. Morelia, 5 km al W de San Miguel del Monte, sobre el camino a Atécuaro, 2400 m, 25 Oct 1986, Rzedowski 41253 (IEB); mpio. Huaniqueo, $5 \mathrm{~km}$ al S de Tendeparacua, 2150 m, 21 Oct 1990, Rzedowski 50335 (IEB); mpio. Epitacio Huerta, cerca de Palmas, 2550 m, 28 Oct 1990, Rzedowski 50513 (IEB). Querétaro: mpio. Huimilpan, alrededores de Huimilpan, 2300 m, 14 Oct 1990, Rzedowski 50302 (IEB); cerca de San Bartolo, 2600 m, 27 Oct 1990, Rzedowski 50436 (IEB); mpio. Huimilpan, 4 km al E de Huimilpan, sobre la carretera a Amealco, 2350 m, 27 Oct 1990, Rzedowski 50463 (IEB); mpio. Amealco, 
$2 \mathrm{~km}$ al N de San Ildefonso, 2400 m, 23 Oct 1991, Rzedowski 51130 (IEB). Zacatecas: mpio. Valparaíso, Puerto de la Paja, ca. $20 \mathrm{~km}$ WSW of Valparaíso, along rd to Huejuquilla el Alto, Jalisco, overgrazed oak woodland, 2250 m, 30 Oct 1963, Feddema 2245 (MICH, a mixed collection with Euphorbia indivisa (Englem.) Tidestr.; the plants of Euphorbia spellenbergiana were indicated with an "A" by McVaugh); \pm 38 $\mathrm{km}$ al W de Jalpa, sobre la carr. a Tlaltenango, $30 \mathrm{~km}$ del entronque con la carr. Jalpa - Juchipila, 2550 m, 21-23 Oct 1973, Rzedowski \& McVaugh 925 (IEB), ibid., 21 Oct 1973, Rzedowski \& McVaugh s.n. (ENCB).

\section{ACKNOWLEDGMENTS}

We gratefully acknowledge funding support to the Instituto de Ecología, A.C. (account number 20006) from the Mexican Consejo Nacional de Ciencia y Tecnología and from the Comisión Nacional para el Conocimiento y Uso de la Biodiversidad, as well as support from an NSF Planetary Biodiversity Inventory grant (DEB-0616533). We thank the curators and staffs of ARIZ, HUAA, IEB, K, MEXU, $\mathrm{MICH}, \mathrm{MO}, \mathrm{NMC}$, and TEX for allowing access to their collections. Rogelio Cárdenas kindly prepared the illustration.

\section{LITERATURE CITED}

Bruyns, P. V., R. J. Mapaya and T.J. Hedderson. 2006. A new subgeneric classification for Euphorbia (Euphorbiaceae) in southern Africa based on ITS and psbA-trnH sequence data. Taxon 55: 397-420.

Davis, H. B. 1936. Life and work of Cyrus Guernsey Pringle. University of Vermont. Burlington. 756 pp.

Martínez-Gordillo, M., J. Jiménez-Ramírez, R. Cruz-Durán, E. Juárez-Arriaga, R. García, A. Cervantes and R. Mejía-Hernández. 2002. Los géneros de la familia Euphorbiaceae en México. Anales Inst. Biol. Univ. Nac. Autón. México, Ser. Bot. 73: 155-281.

Mayfield, M. H. 1991. Euphorbia johnstonii (Euphorbiaceae), a new species from Tamaulipas, Mexico with notes on Euphorbia subsection Acutae. Sida 14(4): 573-579.

Mayfield, M. H. 1993. New combinations in Chamaesyce Gray (Euphorbiaceae) from Texas and the Chihuahuan Desert. Phytologia 75: 178-83.

McVaugh, R. 1993. Euphorbiae Novo-Galiciane revisae. Contr. Univ. Michigan Herb. 19: 207-239.

Park, K.-R. and R. K. Jansen. 2007. A phylogeny of Euphorbieae subtribe Euphorbiinae (Euphorbiaceae) based on molecular data. J. Plant Biol. 50: 644-649. 
Steinmann, V. W. 2002. Diversidad y endemismo de la familia Euphorbiaceae en México. Acta Bot. Mex. 61: 61-93.

Steinmann, V. W. and J. M. Porter. 2002. Phylogenetic relationships in Euphorbieae (Euphorbiaceae) based on ITS and $n d h \mathrm{~F}$ sequence data. Ann. Mo. Bot. Gard. 89: 453-490.

Webster, G. L. 1994. Synopsis of the genera and suprageneric taxa of Euphorbiaceae. Ann. Mo. Bot. Gard. 81: 33-144.

Wheeler, L. C. 1936. Revision of the Euphorbia polycarpa group of the Southwestern United States and adjacent Mexico; a preliminary treatment. Bull. Torr. Bot. Club 63: 397416, 429-450.

Wheeler, L. C. 1941. Euphorbia subgenus Chamaesyce in Canada and the United States exclusive of southern Florida. Rhodora 43: 97-154, 168-205, 223-286; plates 654668 